\title{
Growth inhibitory activity of ethanol extracts of Chinese and Brazilian propolis in four human colon carcinoma cell lines
}

\author{
MASASHI ISHIHARA ${ }^{1,2}$, KUNIKO NAOI $^{1}$, MASANARI HASHITA $^{1}$, YOSHINORI ITOH $^{2}$ and MASUMI SUZUI ${ }^{1}$ \\ ${ }^{1}$ Department of Medical Therapeutics and Molecular Therapeutics, Gifu Pharmaceutical University, 5-6-1 Mitahora-higashi, \\ Gifu 502-8585; ${ }^{2}$ Department of Pharmacy, Gifu University Hospital, 1-1 Yanagido, Gifu 501-1194, Japan
}

Received February 24, 2009; Accepted April 29, 2009

DOI: 10.3892/or_00000444

\begin{abstract}
More than 300 bio-active compounds have been identified from bee propolis in various regions of the world. The objective of this study was to examine whether the ethanol extracts of Chinese and Brazilian propolis may exert anticancer activities in four human colon carcinoma cell lines, namely CaCo2, HCT116, HT29 and SW480. Propolis samples were extracted with ethanol, and the crude extracts were dissolved in dimethylsulfoxide and used for the experiments. In HCT116, HT29 and SW480 cell lines, the extracts of both Chinese and Brazilian propolis caused a marked dose-dependent growth inhibition, with $\mathrm{IC}_{50}$ values in the range of $4-41 \mu \mathrm{g} / \mathrm{ml}$. In HCT116 cell line, Chinese propolis extract induced apoptosis in the cells after $72 \mathrm{~h}$ of treatment. In addition, Chinese propolis extract caused a dose-dependent increase in the cellular mRNA levels of p $21^{\mathrm{CIP} 1}$ and $\mathrm{p} 53$ in the HCT116 cell line. These findings indicate that the ethanol extracts of propolis contain components that may have anticancer activity. Thus, propolis and related products may provide a novel approach to the chemoprevention and treatment of human colon carcinoma.
\end{abstract}

\section{Introduction}

There is growing interest in the use of natural products to aid in the maintenance of human health. Natural products contain a wide variety of chemical compounds that have potent biological effects, including anticancer activity (1). Identification of the active components and their mechanism of action is important to assess their potential for clinical use and possible diverse side effects. Propolis is a natural product derived from various plant resins collected by honeybees, and has been used as a folk medicine for centuries in Europe, North and South America, China and Japan (2). Propolis has been reported to exhibit a broad spectrum of activities

Correspondence to: Dr Masumi Suzui, Department of Medical Therapeutics and Molecular Therapeutics, Gifu Pharmaceutical University, 5-6-1 Mitahora-higashi, Gifu 502-8585, Japan E-mail: suzui@gifu-pu.ac.jp

Key words: propolis, colon carcinoma, apoptosis, chemoprevention including antibacterial, antifungal, antiviral, anti-inflammatory, antioxidant, hepatoprotective, and anticancer properties $(2,3)$. Propolis from Europe, North and South America, Asia and Africa differ in their composition because of the differences in the local vegetation $(2,3)$. The medical application of propolis has led to increased interest in its chemical compositions and its botanical origins since polyphenol compounds and their derivatives have been identified in propolis $(2,3)$.

Colon carcinoma is a common malignancy ranking third in frequency on a world wide basis and causes about 500,000 deaths annually (4). This malignancy is most common in developed countries of Western world, and mortality rate of this disease is rising (4). It is thought that one-third of human carcinoma might be associated with dietary habits and lifestyle (5) and dietary factors are known to be critical modulators of the development of human colon carcinoma $(6,7)$. Despite recent clinical advances, colon carcinoma still remains a major issue because of its incidence, morbidity, and mortality $(4,8,9)$. One promising approach to reduce the incidence and improve the prognosis of this malignancy may be chemoprevention $(1,10)$.

Although the above-described findings are noteworthy, so far there is only a limited number of studies that examined possible anticancer activities of propolis. Therefore, in the present study we used a spectrum of 4 human colon carcinoma cell lines to screen Chinese and Brazilian propolis for their effects on cell proliferation, cell cycle progression, apoptosis, and the levels of expression of cell cycle control molecules.

\section{Materials and methods}

Propolis. Chinese and Brazilian propolis $[26.9 \%(\mathrm{w} / \mathrm{w})]$ was provided by API Company Ltd. (Gifu, Japan) and ground to powder. The powder was extracted with ethanol, filtered and evaporated under reduced pressure to remove ethanol. The remaining crude extracts were dissolved in dimethylsulfoxide (DMSO) (Sigma Chemical Co., St. Louis, MO) at a final concentration of $100 \mathrm{mg} / \mathrm{ml}$ and stored at $-20^{\circ} \mathrm{C}$ until use.

Cell lines and culture. Human colon carcinoma cell lines CaCo2, HCT116, HT29 and SW480 were generously provided by Dr I. Bernard Weinstein (Comprehensive Cancer Center, College of Physicians and Surgeons, Columbia University, New York). Normal human colon epithelial cell line FHC was obtained from American Type Culture 
Collection (ATCC, Manassas, VA). Cells were grown in Dulbecco's modified Eagle's medium (DMEM) (Wako Life Science Reagents, Osaka, Japan) supplemented with $10 \%$ $(\mathrm{v} / \mathrm{v})$ heat-inactivated fetal bovine serum (FBS) (BioWest, Miami, FL) in an incubator with humidified air with $5 \% \mathrm{CO}_{2}$ at $37^{\circ} \mathrm{C}$.

Cell proliferation assays. These assays were performed as recently described $(11,12)$. Cell proliferation was measured by using an MTT assay kit (Roche Diagnostics Corp., Indianapolis, IN) that measures a purple formazan compound produced by viable cells. Cells (700 cell per well) were plated onto 96-well plates in DMEM containing 10\% FBS. After culturing overnight, cells were treated with the indicated concentrations of the extract of Chinese and Brazilian propolis for $72 \mathrm{~h}$. Each concentration was tested in triplicate. After treatment, cells were labeled with $10 \mu \mathrm{M}$ of MTT reagent for $4 \mathrm{~h}$ at $37^{\circ} \mathrm{C}$ and then incubated with $100 \mu \mathrm{M}$ of solubilization solution at $37^{\circ} \mathrm{C}$ overnight. The quantity of formazan product was measured by using a spectrophotometric microtiter plate reader (Multiskan JX, Thermo Fisher Scientific, Yokohama, Japan) at $570 \mathrm{~nm}$ wavelength. The data were analyzed using Ascent Software version 2.6 computer program (Thermo Fisher Scientific). Results were expressed as a percentage of growth (\% cell viability), with $100 \%$ presenting control cells treated with DMSO alone. With the FHC cell line, cell proliferation was also measured by using a Coulter Counter (Z1, Becton-Dickinson, Franklin Lakes, NJ). Cells $\left(1.5 \times 10^{5}\right.$ cells per dish) were plated onto 9-cm-diameter culture dishes and then treated with either DMSO or the indicated concentrations of the extract of Chinese propolis in DMEM containing 10\% FBS for $72 \mathrm{~h}$. After treatment, cells were trypsinized, and the numbers of attached viable cells were counted using a Coulter Counter (Becton-Dickinson). Each concentration of the extract was tested in duplicate. Results were expressed as a percentage of growth (\% cell viability), with $100 \%$ presenting control cells treated with DMSO alone.

Flow cytometry analysis. The analysis was also performed as recently described $(11,12)$. HCT116 and HT29 cells were plated onto $9-\mathrm{cm}$ diameter culture dishes $\left(1.5 \times 10^{5}\right.$ cells per dish) in DMEM plus $10 \%$ FBS and cultured to yield $50-60 \%$ confluence. Cells were then treated with DMSO or 10 and $20 \mu \mathrm{g} / \mathrm{ml}$ extract of Chinese propolis. After $72 \mathrm{~h}$ of treatment, both adherent floating cells were harvested, washed twice with phosphate buffered saline (PBS), fixed with $70 \%$ ethanol, centrifuged, resuspendend in $400 \mu 1$ of $2 \mathrm{mg} / \mathrm{ml}$ RNase (Nacalai Tesque, Kyoto, Japan), stained with $0.1 \mathrm{mg} / \mathrm{ml}$ propidium iodide (PI, Nacalai Tesque), and filtrated through a nylon mesh (Tokyo Screen Co., Ltd., Tokyo, Japan). Flow cytometric analysis was performed on a FACSCalibur instrument (Becton-Dickinson) as previously described $(11,12)$. The distribution of cells in the sub-G1, G1, S and G2-M phases of the cell cycle were calculated using CellQuest Pro computer program (Becton-Dickinson).

Reverse transcription-polymerase chain reaction ( $R T-P C R)$ analysis. These assays were performed by established procedures $(11,12)$. Total RNA was isolated from frozen cells
Table I. Growth inhibitory activities of the ethanol extracts of Chinese and Brazilian propolis samples.

\begin{tabular}{lcc}
\hline & \multicolumn{2}{c}{$\mathrm{IC}_{50}(\mu \mathrm{g} / \mathrm{ml})$} \\
\cline { 2 - 3 } Cell line & Chinese propolis & Brazilian propolis \\
\hline CaCo2 & $>50$ & $>50$ \\
HT29 & $19.0 \pm 1.1$ & $38.9 \pm 0.4$ \\
HCT116 & $12.2 \pm 0.8$ & $41.0 \pm 7.4$ \\
SW480 & $4.4 \pm 0.2$ & $32.5 \pm 11.1$ \\
\hline
\end{tabular}

Each value indicates mean \pm SD.

treated with 10 or $20 \mu \mathrm{g} / \mathrm{ml}$ extracts of Chinese propolis for $72 \mathrm{~h}$ using a TRIzol reagent (Invitrogen Life Technologies, Inc., Rockville, MD) as recommended by the manufacturer. cDNA was amplified from total RNA (100 ng) using a SuperScript III One-Step RT-PCR System (Invitrogen Life Technologies). PCR was conducted for 21-35 cycles in a Takara PCR Thermal Cycler SP TP-400 (Takara Bio Inc., Tokyo, Japan). The primers used for amplification were as follows: p21 ${ }^{\mathrm{CIP} 1}$-specific primer set, C-3F (5'-CCTTAGCCT TCATTCAGTGT-3') and C-4R (5'-GCCAGGATCAGA AACACAGC-3'); p53-specific primer set, P-2F (5'-CAG CGACAGGGTCACCTAAT-3') and P-3R (5'-GTGGAT AGTGGTATAGTCGG-3'). B-actin-specific PCR products for the same RNA samples were simultaneously amplified and served as internal controls. Primers BA-F2 (5'-GGG TATGGGTCAGAAGGACT-3') and BA-R2 (5'-TGTAGC CACGCTCGGTCAGG-3') were used for amplification of B-actin. Each amplification cycle consisted of $0.5 \mathrm{~min}$ at $94^{\circ} \mathrm{C}$ for denaturing, $0.5 \mathrm{~min}$ at $55^{\circ} \mathrm{C}$ for primer annealing, and $1 \mathrm{~min}$ at $72^{\circ} \mathrm{C}$ for extension. PCR products were analyzed by agarose gel electrophoresis and stained with ethidium bromide. The results were confirmed by repeating experiments. mRNA expression levels were analyzed with ImageJ computer program (Image J software, National Institutes of Health, Bethesda, MD).

Statistical analysis. In cell proliferation, flow cytometry and RT-PCR assays, statistical differences between cells treated with DMSO (control) and those treated with each propolis extract were evaluated by Student's t-test. Significance was established at $\mathrm{P}<0.05$.

\section{Results}

Effects of extracts of Chinese and Brazilian propolis on the growth of several human colon carcinoma cell lines. To examine the growth inhibitory activity of each extract from Chinese and Brazilian propolis in several human colon carcinoma cell lines, we generated dose-response curves using MTT assays. In the CaCo2, HCT116, HT29 and SW480 cell lines, extracts from Chinese and Brazilian propolis caused a significant growth inhibition in a dose-dependent manner, with $\mathrm{IC}_{50}$ values in the range of $4-41 \mu \mathrm{g} / \mathrm{ml}$ (Fig. 1 and Table I). The $\mathrm{CaCo} 2$ cell line treated with each extract displayed lower 

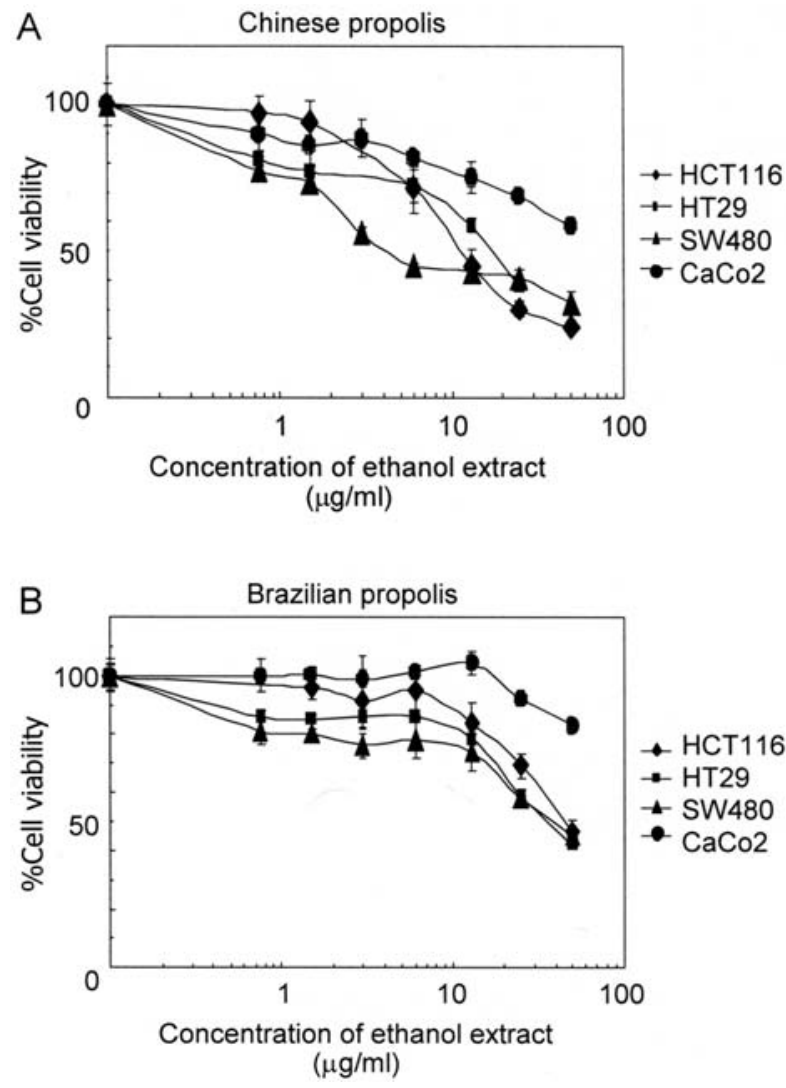

Figure 1. Inhibition of the growth by the extracts of Chinese (A) and Brazilian (B) propolis in four of human colon carcinoma cell lines. Cells were treated with ethanol extracts of propolis in the dose range of $0.75-50 \mu \mathrm{g} / \mathrm{ml}$ for $72 \mathrm{~h}$ in DMEM plus 10\% FBS. Results were expressed as a percentage of growth, with $100 \%$ representing control cells treated with DMSO alone. Each concentration of the extract was examined in triplicate and identical results were obtained.

growth inhibition than that of other 3 human colon carcinoma cell lines when cells were grown for $72 \mathrm{~h}$ (Fig. 1 and Table I). In the HCT116, HT29 and SW480 cell lines the $\mathrm{IC}_{50}$ values of the extract of Chinese propolis were lower than those of Brazilian propolis (Table I), indicating that these cell lines were more sensitive to the extract from Chinese propolis than that from Brazilian propolis. Thus, the SW480 cells were the most sensitive to the extract from Chinese propolis. We then examined whether the extract of Chinese propolis affects the growth of normal human colonic epithelial cells. The FHC, HCT116 and HT29 cell lines were treated with 5-40 $\mu \mathrm{g} / \mathrm{ml}$ propolis extract for $72 \mathrm{~h}$, and then cell viability were determined by generating growth curve using a Coulter Counter (Becton-Dickinson) as described in the Materials and methods section. The extract of Chinese propolis caused only a marginal growth inhibition on the FHC normal human colonic epithelial cell line (Fig. 2). When FHC, HCT116 and HT29 cell lines were treated with $40 \mu \mathrm{g} / \mathrm{ml}$ propolis extract, the growth inhibition rate was about $30 \%$ in the FHC cell line, whereas it was about $90 \%$ in the other 2 cell lines (Fig. 2).

Effects of extract of Chinese propolis on apoptosis. Because we found that the extract of Chinese propolis causes a marked growth inhibition on the HCT116 and HT29 cells, we further investigated whether the extract also induces

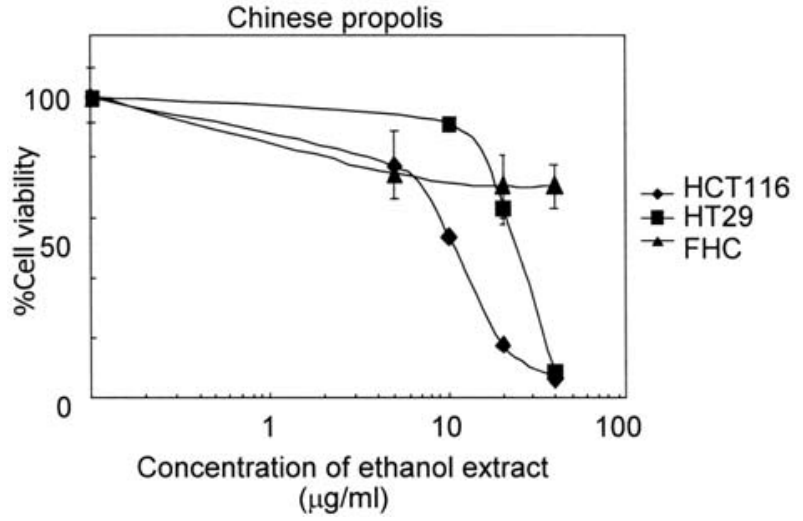

Figure 2. Effects of the ethanol extract of Chinese propolis in HCT116 and HT29 human colon carcinoma cell lines and FHC human normal colonic epithelial cell line. Cells were treated with the indicated concentrations of the extract for $72 \mathrm{~h}$ in DMEM plus $10 \%$ FBS. Results were expressed as a percentage of growth, with $100 \%$ representing control cells treated with DMSO alone. Each concentration of the extract was examined in triplicate and similar results were obtained.

apoptosis in these cell lines. After treating cells with DMSO or 10 and $20 \mu \mathrm{g} / \mathrm{ml}$ propolis extract for $72 \mathrm{~h}$, flow cytometry analysis was performed to detect sub-G1 fraction. In the HCT116 cell line, at concentrations of 10 and $20 \mu \mathrm{g} / \mathrm{ml}$ the extract of Chinese propolis caused a marked increase (up to $15-35 \%)$ in sub-G1 fraction of cells in a dose-dependent fashion (Fig. 3A). The propolis extract $(20 \mu \mathrm{g} / \mathrm{ml})$ caused a significant increase of cells in sub-G1 and this increase was associated with a concomitant relative decrease of cells in the G1, S and G2-M phases of the cell cycle (Fig. 3A). In contrast, sub-G1 fraction did not change in the HT29 cell line (Fig. 3B). In these assays, a significant increase in G1 was not seen in these two cell lines (HCT116 and HT29) after the addition of the propolis extracts.

Effects of extract of Chinese propolis on the levels of expression of specific genes involved in cell cycle control. Since we found that the propolis extracts inhibits the growth of human colon carcinoma cells, it was of interest to examine the effects of the extract of Chinese propolis on cellular mRNA levels of genes that control cell cycle progression and to determine whether p53 status influences the effect of the extract. We treated HCT116 (p53 wild-type) and HT29 (p53 mutant) cells with DMSO (control) or 10 and $20 \mu \mathrm{g} / \mathrm{ml}$ propolis extracts. Total RNA was then isolated at $72 \mathrm{~h}$ after the addition of the extracts. To quantify the expression levels of mRNA, PCR products were generated during both plateau and log-phase reactions by conducting 21-35 cycles of PCR as described in a previous study (13). Using this approach, these products have been shown to reflect corresponding levels of mRNA by Northern blot assays $(14,15)$. In the HCT116 cell line, there was a dose-dependent increase in the band intensity of $\mathrm{p} 21^{\mathrm{CIP} 1} \mathrm{mRNA}$ in samples treated with 10 and $20 \mu \mathrm{g} / \mathrm{ml}$ extracts of Chinese propolis, when compared to samples treated with DMSO alone (Fig. 4). A significant increase in p21 $1^{\mathrm{CIP} 1} \mathrm{mRNA}$ expression was seen in sample treated with $10 \mu \mathrm{g} / \mathrm{ml}$ propolis extract. In contrast, the band intensity of p21 ${ }^{\mathrm{CIP} 1}$ mRNA did not change in the HT29 cell line (Fig. 4). When the HCT116 cells were treated with 
A

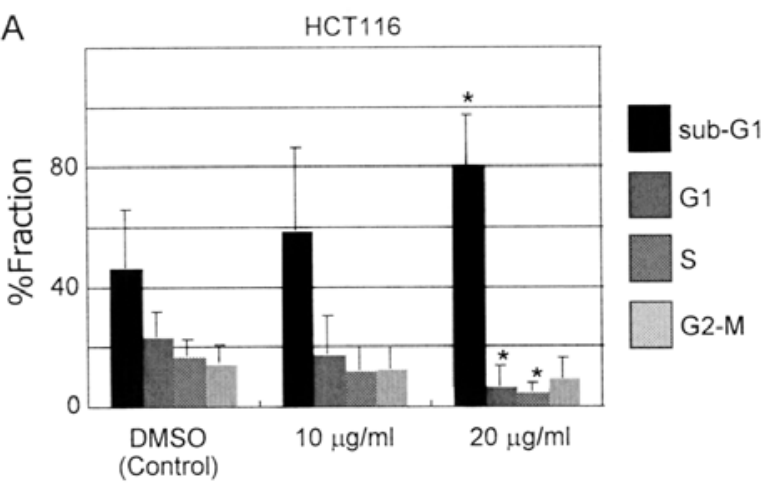

B

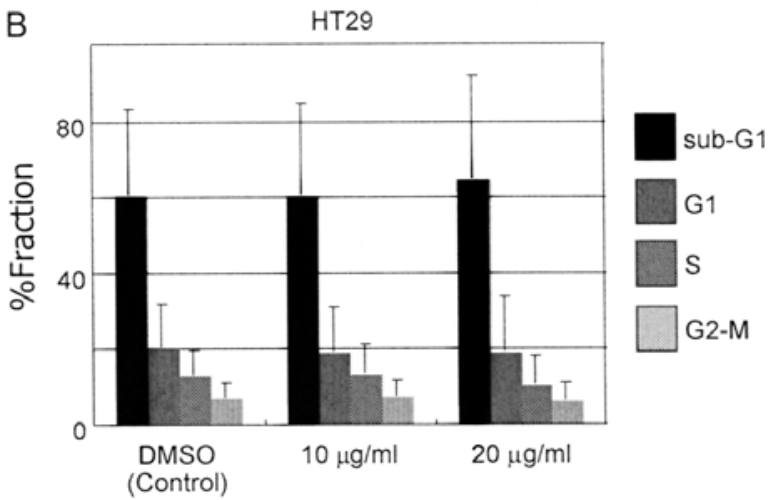

Figure 3. Effects of the ethanol extract of Chinese propolis on cell cycle progression and apoptosis in HCT116 (A) and HT29 (B) cell lines. Cells were treated with DMSO or 10 and $20 \mu \mathrm{g} / \mathrm{ml}$ extract of Chinese propolis for $72 \mathrm{~h}$. The data indicate the percentage of cells in the indicated phase of the cell cycle. Asterisks indicate a statistically significant difference between cells treated with DMSO and the extract $(\mathrm{P}<0.05)$.
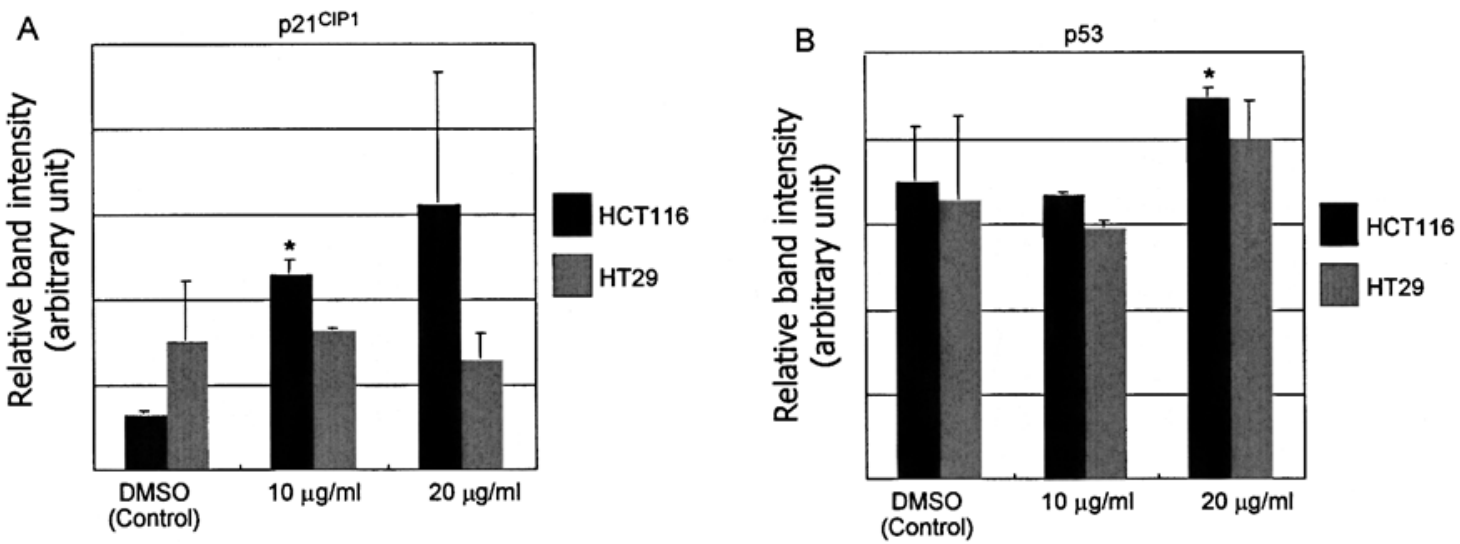

Figure 4. Effects of the extract of Chinese propolis on the cellular mRNA levels of p21 ${ }^{\mathrm{CIP1}}$ (A) and p53 (B). HCT116 and HT29 cells were treated with DMSO (control) or the extract of Chinese propolis for $72 \mathrm{~h}$ in DMEM plus 10\% FBS. B-actin was used as an internal control. The results are the means \pm SD from densitometric analysis representing relative band intensity in each RNA sample. Asterisks indicate a statistically significant difference between cells treated with DMSO and the extract $(\mathrm{P}<0.05)$.

$20 \mu \mathrm{g} / \mathrm{ml}$ propolis extract, there was also a significant increase in band intensity of p53 mRNA but no significant changes were seen in the HT29 cells.

\section{Discussion}

The present studies provide a detailed in vitro examination of the growth inhibitory effects of the crude extracts of Chinese and Brazilian propolis in a variety of human colon carcinoma cell lines. In these studies, we found that the ethanol extracts of both Chinese and Brazilian propolis inhibited the growth of human colon carcinoma cell lines. These results clearly indicate that the ethanol extracts of Chinese and Brazilian propolis contain component(s) that may have antiproliferative activity. The antiproliferative activity of propolis is consistent with those reported to exert biological activities in other types of carcinoma cells. For instance, the Netherlands and Brazilian propolis exhibited antiproliferative activities in murine 26-L5 colon carcinoma, murine B16-BL6 melamona, human HT1080 fibrosarcoma, and human A549 lung adenocarcinoma cell lines $(16,17)$. Also, the Chilean propolis inhibited the growth of human KB mouth epidermoid carcinoma and DU145 androgen intensive prostate carcinoma cell lines
(18). Therefore, our present findings together with the above-described data demonstrate the broad spectrum of antiproliferative properties of the propolis extracts in a various carcinoma cell lines. In the current study, we used four human colon carcinoma cell lines to screen antiproliferative effects of the propolis extracts. Of these, HCT116, HT29 and SW480 cell lines were more sensitive to growth inhibition by the propolis extracts because $\mathrm{CaCo} 2$ cell line requires much higher concentration $(>50 \mu \mathrm{g} / \mathrm{ml})$ of the extract for growth inhibition than the other 3 cell lines (Table I). In a previous study, it is demonstrated that highly proliferating cells are critical to growth inhibition by the extract of Bilberry (Vaccinium myrtillus) (19). The growing rate of the HCT116 and SW480 cell line is as about 5 to 10 times higher than that of the $\mathrm{CaCo} 2$ cell line (20). In the current study the extract of Chinese propolis showed only a marginal growth inhibition in human normal colonic epithelial cells, whereas in HCT116 and HT29 colon carcinoma cells the extract caused a marked and sustained decrease in growth. These findings may explain why susceptibility to growth inhibition differs depending on cell lines.

More than 300 compounds have been identified in propolis products. These include flavonoids, polyphenols, phenolic 
aldehydes, terpenoids, coumarines, amino acids, steroids and inorganic compounds (2). Propolis products originating from Europe and China contain many types of flavonoids and phenolic acid esters (21), whereas propolis of Brazilian origin is composed mainly of artepillin $\mathrm{C}$, terpenoids and prenylated derivatives of $p$-coumaric acid $(22,23)$. Benzyl caffeate and phenethyl caffeate isolated from the methanol extract of Chinese propolis do exert antiproliferative activity in murine colon carcinoma cells (21). It has also been demonstrated that the ethanol extracts of propolis derived from the Netherlands and China show a marked cytotoxicity, while the Brazilian and Peruvian propolis extracts exhibit mild cytotoxicity (16). The constituents of propolis depend on the phyto-geographical factors such as plant sources, specific location of plant distribution, and seasonal time periods (2). These factors may influence the biological activities and amount of active components of propolis. We found that the extracts of Chinese propolis exhibit stronger growth inhibitory effects than that of Brazilian propolis (Fig. 1 and Table I), indicating that the chemical composition of propolis may differ depending on the above-described factors.

Because we found that the propolis extracts inhibit the growth of human colon carcinoma cells, we further determined whether the extracts induce apoptosis in these cells. In the current study, treatment of human colon carcinoma cells with Chinese propolis extracts at dose levels of 10 and $20 \mu \mathrm{g} / \mathrm{ml}$ caused a marked sub-G1 fraction in flow cytometry analysis, indicating that Chinese propolis is a powerful inducer of apoptosis in human colon carcinoma cells. Thus, the growth inhibitory activity of propolis may be associated with the induction of apoptosis. The present results are in accordance with previous studies demonstrating that ethanol extracts and a compound propolin isolated from Taiwanese propolis induce apoptosis in human A2058 melanoma cells $(24,25)$.

p $21^{\mathrm{CIP} 1}$ is of particular interest since this molecule plays a critical role in the development of human colon carcinogenesis by negatively regulating the activity of cyclin D1cyclin- dependent kinase (CDK) complex via a p53-dependent or independent mechanism (26). In the present study, we therefore examined the expression levels of p21 ${ }^{\mathrm{CIP} 1}$ and $\mathrm{p} 53$ mRNA. In p53 wild-type HCT116 cells, the extract of Chinese propolis caused a dose-dependent increase in the cellular mRNA levels of $\mathrm{p} 21^{\mathrm{CIP} 1}$ and $\mathrm{p} 53$. In contrast, in HT29, a p53-mutant cell line, the mRNA expression levels of these two genes did not change. The results presumably indicate that p53 status, at least in part, is critical to the antiproliferative activity of propolis in HCT116 human colon carcinoma cells. It is well known that wild-type p53 induces apoptosis (27). Therefore, these findings suggest that the induction of $\mathrm{p} 21^{\mathrm{CIP} 1}$ and $\mathrm{p} 53$ may cooperate with the induction of apoptosis and thereby further contribute to growth inhibition by propolis in the wild-type p53 expressing HCT116 cells (28). As such, we questioned why p53-mutant cell lines HT29 and SW480 (29) are sensitive to the treatment of the propolis extract. p53-independent pathways may be involved but this issue warrants further investigation. Most patients with colorectal carcinoma present an increased expression of cyclooxygenase-2 (COX-2) in their neoplastic tissues (30). Thus, we also examined the expression levels of COX-2 mRNA in HT29 cells since these cells highly express COX-2 that is only slightly expressed by HCT116 cells $(31,32)$. The extract $(10$ and $20 \mu \mathrm{g} / \mathrm{ml})$ of Chinese propolis decreased the cellular expression of COX-2 mRNA by about $20-35 \%$ in HT29 cells (data not shown).

Among the more than 300 compounds identified in propolis samples (2), caffeic acid phenethyl ester (CAPE) inhibit the growth and induce G1-phase arrest and apoptosis in HCT116 and SW480 cells, by decreasing mRNA and protein expression of cyclin D1 and c-myc $(33,34)$. In human HT1080 fibrosarcoma cells CAPE also decrease mRNA expression of matrix metalloproteinase (MMP) that plays a pivotal role in tumor metastasis by cleavage of extracellular matrix (35). Chrysin has been shown to exert anti-inflammatory and anti-carcinogenic effects through the inhibition of mRNA expression of interleukin-1ß (IL-1ß), inducible nitric oxide synthase (iNOS), and COX-2 (36,37). Artepillin C derived from Brazilian propolis caused a dose-dependent decrease in growth of $\mathrm{CaCc} 2$ human colon carcinoma cells, and it arrested the cells in G0/G1 phase via a stimulation of $\mathrm{p} 21^{\mathrm{CIP} 1}$ mRNA expression (38). In addition to in vitro studies, aqueous and ethanol extracts of Brazilian propolis can suppress the occurrence of azoxymethane-induced aberrant crypt foci $(\mathrm{ACF})$ in rats (39). It has also been reported recently that dietary artepillin $\mathrm{C}$ inhibits the formation of ACF in mice (40).

The current studies provide evidence that the ethanol extracts of Chinese and Brazilian propolis inhibit the growth and induce apoptosis in cell cultures of human colon carcinoma cells, strongly indicating that the extracts contain components possessing anticancer activity. It is of interest whether the ethanol extract of propolis is useful in the chemoprevention of and/or chemotherapy of human colon carcinoma. Thus, the important consideration is whether or not, following oral administration, sufficient blood and tissue levels can be achieved and whether the extract exerts significant adverse side effects. To address these issues, further studies are in progress to identify the active component of the extracts and the precise molecular mechanism by which the extracts inhibit the growth of human colon carcinoma cells.

\section{Acknowledgements}

This study is dedicated to the memory of the late Dr I. Bernard Weinstein.

\section{References}

1. Sporn MB and Suh N: Chemoprevention of cancer. Carcinogenesis 21: 525-530, 2000.

2. Khalil ML: Biological activity of bee propolis in health and disease. Asian Pac J Cancer Prev 7: 22-31, 2006.

3. Burdock GA: Review of the biological properties and toxicity of bee propolis (propolis). Food Chem Toxicol 36: 347-363, 1998.

4. Parkin DM: Global cancer statistics in the year 2000. Lancet Oncol 2: 533-543, 2001.

5. Wynder EL, Kajitani T, Ishikawa S, Dodo $\mathrm{H}$ and Takano A: Environmental factors of cancer of the colon and rectum. II. Japanese epidemiological data. Cancer 23: 1210-1220, 1969.

6. Reddy BS: Nutritional factors and colon cancer. Crit Rev Food Sci Nutr 35: 175-190, 1995.

7. Willett WC, Stampfer MJ, Colditz GA, Rosner BA and Speizer FE: Relation of meat, fat, and fiber intake to the risk of colon cancer in a prospective study among women. N Engl J Med 323: 1664-1672, 1990.

8. McWilliams RR and Erlichman C: Novel therapeutics in colorectal cancer. Dis Colon Rectum 48: 1632-1650, 2005. 
9. Parkin DM, Bray F, Ferlay J and Pisani P: Global cancer statistics, 2002. CA Cancer J Cli 55: 74-108, 2005.

10. Sporn MB: Approaches to prevention of epithelial cancer during the preneoplastic period. Cancer Res 36: 2699-2702, 1976.

11. Suzui M, Inamine M, Kaneshiro T, et al: Indole-3-carbinol inhibits the growth of human colon carcinoma cells but enhances the tumor multiplicity and volume of azoxymethaneinduced rat colon carcinogenesis. Int J Oncol 27: 1391-1399, 2005.

12. Suzui M, Sunagawa N, Chiba I, Moriwaki H and Yoshimi N: Acyclic retinoid, a novel synthetic retinoid, induces growth inhibition, apoptosis, and changes in mRNA expression of cell cycle- and differentiation-related molecules in human colon carcinoma cells. Int J Oncol 28: 1193-1199, 2006.

13. Joe AK, Liu H, Suzui M, Vural ME, Xiao D and Weinstein IB: Resveratrol induces growth inhibition, S-phase arrest, apoptosis, and changes in biomarker expression in several human cancer cell lines. Clin Cancer Res 8: 893-903, 2002.

14. Suzui M, Masuda M, Lim JT, Albanese C, Pestell RG and Weinstein IB: Growth inhibition of human hepatoma cells by acyclic retinoid is associated with induction of p21(CIP1) and inhibition of expression of cyclin D1. Cancer Res 62: 3997-4006, 2002.

15. Suzui M, Shimizu M, Masuda M, Lim JT, Yoshimi N and Weinstein IB: Acyclic retinoid activates retinoic acid receptor beta and induces transcriptional activation of p21(CIP1) in HepG2 human hepatoma cells. Mol Cancer Ther 3: 309-316, 2004.

16. Banskota AH, Nagaoka T, Sumioka LY, et al: Antiproliferative activity of the Netherlands propolis and its active principles in cancer cell lines. J Ethnopharmacol 80: 67-73, 2002.

17. Li F, Awale S, Tezuka Y and Kadota S: Cytotoxic constituents from Brazilian red propolis and their structure-activity relationship. Bioorg Med Chem 16: 5434-5440, 2008

18. Russo A, Cardile V, Sanchez F, Troncoso N, Vanella A and Garbarino JA: Chilean propolis: antioxidant activity and antiproliferative action in human tumor cell lines. Life Sci 76: $545-558,2004$

19. Katsube N, Iwashita K, Tsushida T, Yamaki K and Kobori M: Induction of apoptosis in cancer cells by Bilberry (Vaccinium myrtillus) and the anthocyanins. J Agric Food Chem 51: 68-75, 2003

20. Maoret JJ, Anini Y, Rouyer-Fessard C, Gully D and Laburthe M Neurotensin and a non-peptide neurotensin receptor antagonist control human colon cancer cell growth in cell culture and in cells xenografted into nude mice. Int J Cancer 80: 448-454, 1999.

21. Usia T, Banskota AH, Tezuka Y, Midorikawa K, Matsushige K and Kadota S: Constituents of Chinese propolis and their antiproliferative activities. J Nat Prod 65: 673-676, 2002.

22. Ahn MR, Kunimasa K, Ohta T, et al: Suppression of tumorinduced angiogenesis by Brazilian propolis: major component artepillin $\mathrm{C}$ inhibits in vitro tube formation and endothelial cell proliferation. Cancer Lett 252: 235-243, 2007.

23. Li H, Kapur A, Yang JX, et al: Antiproliferation of human prostate cancer cells by ethanolic extracts of Brazilian propolis and its botanical origin. Int J Oncol 31: 601-606, 2007.

24. Chen CN, Weng MS, Wu CL and Lin JK: Comparison of radical scavenging activity, cytotoxic effects and apoptosis induction in human melanoma cells by Taiwanese propolis from different sources. Evid Based Complement Alternat Med 1: $175-185,2004$.
25. Chen CN, Wu CL and Lin JK: Apoptosis of human melanoma cells induced by the novel compounds propolin A and propolin B from Taiwanese propolis. Cancer Lett 245: 218-231, 2007.

26. Weinstein IB: Disorders in cell circuitry during multistage carcinogenesis: the role of homeostasis. Carcinogenesis 21: 857-864, 2000.

27. Yonish-Rouach E, Resnitzky D, Lotem J, Sachs L, Kimchi A and Oren M: Wild-type p53 induces apoptosis of myeloid leukaemic cells that is inhibited by interleukin-6. Nature 352: 345-347, 1991.

28. Lin-Lee YC, Tatebe S, Savaraj N, Ishikawa T and Tien Kuo M: Differential sensitivities of the MRP gene family and gammaglutamylcysteine synthetase to prooxidants in human colorectal carcinoma cell lines with different p53 status. Biochem Pharmacol 61: 555-563, 2001

29. Toscano F, Fajoui ZE, Gay F, et al: P53-mediated upregulation of DcR1 impairs oxaliplatin/TRAIL-induced synergistic antitumour potential in colon cancer cells. Oncogene 27: 4161-4171, 2008.

30. Hartwich A, Konturek SJ, Pierzchalski P, et al: Helicobacter pylori infection, gastrin, cyclooxygenase-2, and apoptosis in colorectal cancer. Int J Colorectal Dis 16: 202-210, 2001.

31. Colucci R, Blandizzi C, Ghisu N, Florio T and Del Tacca M: Somatostatin inhibits colon cancer cell growth through cyclooxygenase-2 downregulation. Br J Pharmacol 155: 198-209, 2008.

32. Liu Q, Chan ST and Mahendran R: Nitric oxide induces cyclooxygenase expression and inhibits cell growth in colon cancer cell lines. Carcinogenesis 24: 637-642, 2003.

33. He YJ, Liu BH, Xiang DB, Qiao ZY, Fu T and He YH: Inhibitory effect of caffeic acid phenethyl ester on the growth of SW480 colorectal tumor cells involves beta-catenin associated signaling pathway down-regulation. World J Gastroenterol 12: 4981-4985, 2006

34. Xiang D, Wang D, He Y, et al: Caffeic acid phenethyl ester induces growth arrest and apoptosis of colon cancer cells via the beta-catenin/T-cell factor signaling. Anticancer Drugs 17: 753-762, 2006

35. Hwang HJ, Park HJ, Chung HJ, et al: Inhibitory effects of caffeic acid phenethyl ester on cancer cell metastasis mediated by the down-regulation of matrix metalloproteinase expression in human HT1080 fibrosarcoma cells. J Nutr Biochem 17: 356-362, 2006.

36. Blonska M, Bronikowska J, Pietsz G, Czuba ZP, Scheller S and Krol W: Effects of ethanol extract of propolis (EEP) and its flavones on inducible gene expression in J774A.1 macrophages. J Ethnopharmacol 91: 25-30, 2004.

37. Woo KJ, Jeong YJ, Inoue H, Park JW and Kwon TK: Chrysin suppresses lipopolysaccharide-induced cyclooxygenase-2 expression through the inhibition of nuclear factor for IL-6 (NF-IL6) DNA-binding activity. FEBS Lett 579: 705-711, 2005.

38. Shimizu K, Das SK, Hashimoto T, et al: Artepillin C in Brazilian propolis induces $\mathrm{G}(0) / \mathrm{G}(1)$ arrest via stimulation of Cip1/p21 expression in human colon cancer cells. Mol Carcinog 44: 293-299, 2005

39. Yasui Y, Miyamoto S, Kim M, Kohno H, Sugie S and Tanaka T: Aqueous and ethanolic extract fractions from the Brazilian propolis suppress azoxymethane-induced aberrant crypt foci in rats. Oncol Rep 20: 493-499, 2008.

40. Shimizu K, Das SK, Baba M, Matsuura Y and Kanazawa K: Dietary artepillin $\mathrm{C}$ suppresses the formation of aberrant crypt foci induced by azoxymethane in mouse colon. Cancer Lett 240: 135-142, 2006 